Аблиев Тимур Маратович

аспирант кафедры уголовного права и процесса Казанского инновационного университета им. В.Г. Тимирясова,

помощник Бугульминского городского прокурора

Республики Татарстан

\section{ТЕОРЕТИЧЕСКИЕ ПРОБЛЕМЫ АНТИКОРРУПЦИОННОЙ ЭКСПЕРТИЗЫ МУНИЦИПАЛЬНЫХ НОРМАТИВНЫХ ПРАВОВЫХ АКТОВ И ПРОЕКТОВ МУНИЦИПАЛЬНЫХ НОРМАТИВНЫХ ПРАВОВЫХ АКТОВ}

\section{Аннотация:}

Исследования теоретических проблем института антикоррупционной экспертизы муниципальных нормативных правовых актов и проектов муниципальных нормативных правовых актов требуют большого внимания. В статье проанализированы подходы к определению предмета и объекта оценки и установлены предмет и объект оценки муниципальных продуктов правотворчества. Рассмотрены вопросы, связанные с ограничением уча стия органов прокуратуры в антикоррупционной экспертизе муниципальных актов и проектов муниципальных нормативных правовых актов. Предложен альтернативный взгляд на роль субъектов независимой экспертизы муниципальных нормативных правовых актов и проектов таких актов. Обоснована необходимость участия таких субъектов в антикоррупционной экспертизе.

Ключевые слова:

антикоррупционная экспертиза, местное самоуправление, муниципальные нормативные правовые акты, средство противодействия коррупции.
Abliev Timur Maratovich

PhD student Criminal Law and Process Department, Kazan Innovative University, Bugulma City Prosecutor's Assistant Republic of Tatarstan

THEORETICAL ISSUES OF ANTI-CORRUPTION ASSESSMENT OF MUNICIPAL LAWS AND REGULATIONS AND THEIR DRAFTS

Summary:

Theoretical issues of anti-corruption assessment of municipal laws and regulations and their drafts require much attention. The article analyzes the approaches to defining the subject and object of assessment and identifies the subject and object of assessment of municipal lawmaking elements. The study reviews issues related to limited participation of prosecutors in anticorruption assessment of municipal laws and regulations and their drafts. The author proposed an alternative view on the role of an independent assessment entities of municipal laws and regulations and their drafts. The paper substantiates the necessity of such entities' participation in the anti-corruption assessment.

Keywords: anti-corruption assessment, local government, municipal laws and regulations, anti-corruption tool.

Противодействие коррупции является весьма актуальной проблемой. Одним из средств противодействия коррупции в соответствии со ст. 6 федерального закона «О противодействии коррупции» выступает антикоррупционная экспертиза нормативных правовых актов и проектов нормативных правовых актов, что свидетельствует о важности данного правового института [1]. Количество нормативных правовых актов, принимаемых на муниципальном уровне, значительно превышает аналогичный показатель актов, принятых государственными органами [2]. Учитывая тот факт, что на незаконные правовые акты органов местного самоуправления, прямо затрагивающие права и свободы граждан, ежегодно прокуратурой приносится около 180 тыс. протестов, подобное состояние дел создает реальную угрозу для правовой системы России [3].

Необходимость антикоррупционной экспертизы муниципальных нормативных правовых актов и проектов муниципальных нормативных правовых актов закрепляется и в законах о противодействии коррупции некоторых субъектов Российской Федерации. Так, например, в Республике Татарстан закрепили, что антикоррупционная экспертиза проводится в том числе в отношении нормативных правовых актов органов местного самоуправления [4]. Данное положение выражает позицию законодателя субъекта РФ о необходимости дальнейшего закрепления и развития такого вида антикоррупционной экспертизы, как экспертиза муниципальных нормативных правовых актов и проектов муниципальных нормативных правовых актов. Следовательно, данный правовой институт должен быть изучен с применением комплексного подхода исследования с точки зрения как практики, так и теории.

Многочисленные исследования соотношения теории и практики подтверждают, что они взаимно обусловлены и оказывают воздействие друг на друга. Между ними периодически возникает противоречие, преодоление которого влечет развитие и теории, и практики. Поэтому отмечается, что добросовестная научная теория выступает критерием правильности практики и может коррек- 
тировать последнюю в случае необходимости [5]. Несмотря на большое значение антикоррупционной экспертизы муниципальных нормативных правовых актов и их проектов в качестве действенного инструмента противодействия коррупции, ограничиваться рассмотрением лишь практических проблем оценки неверно. Теоретическая конструкция помогает эксперту правильно подобрать и применить стратегию и методологию оценки, что позитивно отразится на качестве последней.

Первой проблемой, требующей разрешения, представляется определение предмета и объекта исследования муниципальных актов и их проектов на коррупциогенность. Однако единое мнение относительно предмета и объекта антикоррупционной экспертизы нормативных правовых актов и их проектов отсутствует. Поэтому также рассмотрим позиции различных авторов касательно объекта и предмета оценки на коррупциогенность в целом.

Известна исследовательская природа экспертизы [6, с. 173], поэтому прежде следует обратиться к определению предмета и объекта исследования в других научных сферах.

В гносеологии под объектом познания понимается окружающая действительность, противостоящая субъекту познания. При этом отмечается, что противопоставление объекта и предмета исследования с общегносеологической точки зрения является условным и относительным [7]. Поэтому при определении предмета исследования правильнее обратиться к логике и методологии науки. Там предмет исследования, противопоставляемый его объекту, определяется как свойство или сторона объекта, рассматриваемые в конкретном исследовании [8]. Так, объектом социологического исследования выступают определенные общественные отношения, институты или процессы, в которых лучше всего выражен предмет исследования. Предмет, в свою очередь, является свойством, характеристикой объекта исследования, например общественных отношений [9].

Противопоставление предмета исследования его объекту обосновывается в методологии научного исследования с нескольких позиций. Во-первых, предмет определяется в результате познавательных операций с объектом, в то время как сам объект существует независимо от субъекта познания. Во-вторых, один и тот же объект часто изучается различными науками, имеющими при этом специфрический предмет познания. Наконец, предмет и объект не совпадают по своей структуре. Если структура объекта является взаимодействием его основных элементов, то структура предмета обусловливается существующим уровнем познания объекта.

Положений гносеологии и методологии научного исследования придерживаются и при обосновании предмета и объекта судебной экспертизы. Объектом в данном случае называют материальные сущности и различные процессы, содержащие сведения, необходимые для разрешения задачи экспертизы [10], - то есть элементы той самой окружающей действительности, противостоящей эксперту. За предмет судебной экспертизы принимают свойства объекта, исследуемые с целью получения сведений, необходимых для установления фактов-доказательств [11]. Такое определение предмета полностью соответствует положениям логики и методологии научного исследования.

Рассмотренные подходы к определению предмета и объекта исследования будут полезны при дальнейшем анализе авторских позиций относительно предмета и объекта антикоррупционной экспертной оценки нормативных правовых актов и их проектов.

Первым подходом, требующим рассмотрения, представляется определение объекта экспертизы как правовых актов и их проектов, предусматривающих действия, обязывающие регулировать или охранять общественные отношения представителей власти [12], а предмета, соответственно, как административных процедур, предусмотренных в упомянутых правовых актах или их проектах [13].

Принятие нормативного правового акта или его проекта в качестве объекта экспертизы обосновано многими авторами [14]. Однако рассматриваемый подход подвергается справедливой критике в первую очередь в связи с узостью выбранного предмета экспертизы, так как коррупциогенность акта может быть обусловлена не дефектностью административной процедуры, им предусмотренной, а недостатком материальных норм или пробелами в правовом регулировании $[15$, с. 15]. И оценка только административной процедуры (если она присутствует) будет неэффективной с точки зрения противодействия коррупции. Соответственно, объект экспертизы также подвергается необоснованной коррекции, так как акт может вовсе не содержать никаких административных процедур, т. е. не регулировать действия представителей власти. Он может иметь материально-правовую природу [16].

Некоторые авторы принимают за объект экспертизы общественные отношения по проверке актов и их проектов на наличие коррупциогенных фракторов и их устранению [17]. 3десь кроется заблуждение о соотношении антикоррупционной экспертизы как проектно-исследовательской деятельности, направленной на выявление и устранение коррупциогенных факторов, и исследования, направленного на изучение самой антикоррупционной экспертизы.

Третий подход, сформировавшийся в юридической доктрине, принимает за предмет оценки нормативный правовой акт или его проект, а за объект - общественные отношения, на регулирование которых направлен нормативный правовой акт [18]. Он также был подвергнут 
обоснованной критике А.О. Мелешко, поэтому дополнительное его рассмотрение нецелесообразно. Однако будет продуктивным рассмотреть данный подход, приняв за объект экспертизы акт или его проект, а за предмет - общественные отношения, регулируемые актом или претендующим на их регулирование проектом акта, чтобы избежать еще одного заблуждения в определении предмета экспертизы.

В таком случае положительной чертой подхода следует признать расширение объекта экспертизы с акта или проекта акта, содержащих административную процедуру, до любого из них. Такой позиции придерживаются сторонники подходов, которые будут раскрыты далее. В дальнейшем будем рассматривать лишь различные взгляды на предмет экспертизы.

Общественные отношения не могут являться предметом антикоррупционной экспертной оценки акта или его проекта, так как в таком случае не будет выполнена ее основная зада выявление и устранение коррупциогенных фракторов. Оценка позволит судить лишь о подверженности коррупции регулируемых актом общественных отношений. Даже обнаружив ее, эксперт не выявит причину такой подверженности и, соответственно, не устранит ее. Таким образом, антикоррупционная экспертиза потеряет свой статус инструмента противодействия коррупции и свою проектную составляющую.

Принимать за предмет экспертизы коррупциогенный фактор, что делают представители четвертого подхода [19], также не совсем верно. Как справедливо отмечает А.О. Мелешко, акт может их не содержать вовсе [20]. Тем не менее экспертиза акта должна проводиться. Это было бы невозможным в случае отсутствия предмета экспертизы. Поэтому выявленный и устраненный коррупциогенный фрактор является скорее результатом проведенной оценки, нежели ее предметом.

Последний подход, требующий рассмотрения, сформировался недавно. Придерживаясь общей позиции касательно объекта экспертизы (принимая за него нормативный правовой акт и проект нормативного правового акта), он устанавливает в качестве предмета оценки характер связи объекта с коррупционным поведением. Исследуя акт или проект акта, эксперт выясняет, насколько они способствуют (могут способствовать) возникновению коррупции, то есть устанавливает наличие коррупциогенности акта. Это и есть свойство, на исследование которого направлена экспертиза. Также в случае антикоррупционной направленности акта или проекта акта экспертиза определяет, насколько эффрективно они будут реализовать свое предназначение [21]. Такой взгляд на предмет антикоррупционной экспертизы нормативных правовых актов и проектов нормативных правовых актов является наиболее правильным. Выявив, как именно нормативный правовой акт или его проект порождает коррупционную преступность, эксперт сможет верно определить коррупциогенный фрактор, найти способ его устранения, чтобы исключить связь положений акта с какими-либо коррупционными проявлениями.

Таким образом, объектом антикоррупционной экспертной оценки муниципальных нормативных правовых актов и проектов муниципальных нормативных правовых актов будут выступать сами такие акты и проекты. Предметом будет являться характер их связи с коррупционным поведением в сфере местного самоуправления. Такой взгляд на объект и предмет экспертизы муниципальных актов и их проектов должен учитываться при подготовке экспертов в данной области. Также определение объекта и предмета будет способствовать разработке и совершенствованию методик и порядков проведения оценки муниципальных актов и проектов муниципальных актов.

Далее необходимо рассмотреть проблему, касающуюся субъектов оценки муниципальных актов и проектов таких актов. Для этого требуется ответить на несколько вопросов. Во-первых, обоснованно ли с точки зрения интересов местного самоуправления участие в оценке органов прокуратуры. Во-вторых, кто является субъектом независимой экспертизы муниципальных нормативных правовых актов и проектов муниципальных нормативных правовых актов. В-третьих, каково содержание статуса граждан - жителей муниципального образования в качестве субъектов антикоррупционной экспертной оценки нормативных правовых актов и проектов нормативных правовых актов данного муниципального образования. Полагаем невозможным дать всеобъемлющий ответ на приведенные вопросы, однако постараемся начать разработку перечисленных проблем и надеемся на дальнейшую научную дискуссию.

Первый вопрос - вопрос об обоснованности участия органов прокуратуры - является частью более обширной проблемы взаимодействия органов государственной власти и местного самоуправления и важен с точки зрения идеи местного самоуправления в целом. Его игнорирование может привести к нивелированию функции по противодействию коррупции в случае фактического превращения оценки в инструмент притеснения местного самоуправления. Нельзя не согласиться с М.Ю. Каверзиным: эфффективная и плодотворная деятельность государства, в том числе в области противодействия коррупции, возможна лишь при наличии жизнеспособной системы местного самоуправления [22].

Представляется, что лучше всего, если взаимодействие государства и местного самоуправления будет осуществляться на основе концепции взаимодействия. Концепция заключается в том, что эти две организационные формы осуществления власти народа обладают определенной самостоятельностью, однако в их деятельности прослеживается взаимосвязь [23]. 
«Немногие исследователи знают достаточно о конституционных, политических и налоговых связях государства и муниципальных образований, еще меньше исследователей представляют о комплексном их взаимодействии в создании общественных благ. Разработка (проблем взаимодействия. - Т. А.) останавливается из-за отсутствия определенности в отношениях государства и местного самоуправления...» [24]. Отмечается и наличие над местным самоуправлением надзора со стороны не только местного населения, но и органов государственной власти.

Можно отметить, что и законодательство РФ строится на основании концепции взаимосвязи.

Согласно фредеральному закону «Об общих принципах организации местного самоуправления в Российской Федерации» местное самоуправление в Российской Федерации осуществляется в пределах, установленных Конституцией РФ, федеральными законами и законами субъектов Российской Федерации (ст. 1). При этом население муниципального образования и органы местного самоуправления вправе принимать в приведенных выше пределах муниципальные нормативные правовые акты по вопросам местного значения. Таким образом, правотворчество является частью местного самоуправления и продолжением права граждан на осуществление местного самоуправления. Это подтверждается и ст. 22, 26, 43 упомянутого закона. Соответственно, органы прокуратуры, осуществляя антикоррупционную экспертизу, определенным образом участвуют в правотворчестве. Также возникает вопрос: не ограничивается ли таким участием конституционное право граждан на осуществление местного самоуправления?

Следует учесть и некоторые другие положения закона. Так, пункт 2 ст. 5 закрепляет, что осуществление контрольных полномочий в отношении муниципалитетов и их органов фредеральными органами государственной власти возможно лишь в случае и порядке, предусмотренных Конституцией РФ, Законом об общих принципах организации местного самоуправления и другими федеральными законами. Данная норма соответствует положению о контроле и надзоре за местными органами власти со стороны государства, входящему в концепцию взаимосвязи. С этим положением перекликаются нормы, содержащиеся в ст. 43.1 и п. 6 ст. 44 закона. Они созданы в целях обеспечения верховенства Конституции РФ, фредеральных законов и некоторых конституционных прав граждан [25].

Для того чтобы сделать окончательный вывод об обоснованности или необоснованности проведения антикоррупционной экспертной оценки муниципальных нормативных правовых актов и проектов муниципальных правовых актов, следует обратиться к другому закону - фредеральному закону «О прокуратуре Российской Федерации».

Статья 1 вышеуказанного закона закрепляет, что органы прокуратуры Российской Федерации осуществляют надзор за соблюдением Конституции РФ и исполнением федеральных законов, действующих на территории России, в том числе в сфере местного самоуправления. Пункт 2 ст. 4 устанавливает, что органы прокуратуры РФ осуществляют свои полномочия независимо от органов местного самоуправления. Также важно учесть цели деятельности прокуратуры: обеспечение верховенства закона, единства и укрепления законности, защиты прав и свобод человека и гражданина, охраняемых законом интересов общества и государства (ст. 1).

Таким образом, органы прокуратуры выступают институциональной формой надзора и контроля над органами местного самоуправления со стороны государства, которую предусматривает реализуемая в законодательстве РФ концепция взаимосвязи в отношениях государственной власти и местного самоуправления. Такой контроль обусловливается необходимостью совместной деятельности органов государственной власти и органов местного самоуправления в целях выполнения задач национального масштаба. Также государственный контроль деятельности местного самоуправления позволяет защитить граждан от притеснения их прав и свобод [26]. Те же цели преследует оценка уставов муниципальных образований и актов об изменениях, в него вносящихся.

Реализация этой идеи подтверждается пунктом 2 ст. 3 федерального закона «Об антикоррупционной экспертизе нормативных актов и проектов нормативных актов», согласно которому прокуроры проводят антикоррупционную экспертную оценку нормативных правовых актов, касающихся прав и свобод и обязанностей граждан, государственной и муниципальной собственности и службы (в том числе социальных гарантий, с ней связанных), а также важных сфер законодательства.

Второй вопрос, требующий ответа, назрел при рассмотрении правового регулирования антикоррупционной экспертизы муниципальных нормативных правовых актов и проектов таких актов в муниципальных «Порядках». Как уже было отмечено, в них используются две разные формулировки, вносящие различный смысл в понятие субъекта независимой антикоррупционной экспертизы. Одна из формулировок устанавливала в качестве субъекта такой экспертизы институты гражданского общества и граждан, а другая - физических и юридических лиц, аккредитованных Министерством юстиции в качестве независимых экспертов. Несомненно, это как раз тот случай, когда практика нуждается в ответе со стороны теории. Правомерен уже приведенный вопрос: кто является субъектом независимой экспертизы муниципальных нормативных правовых актов и проектов муниципальных нормативных правовых актов? 
К сожалению, данный вопрос в доктринальной среде поднимался редко, а большинство авторов его вовсе не затрагивали или затрагивали вскользь. Тем не менее можно отследить некоторые парадигмы, которых придерживаются те или иные исследователи. Первые отстаивают позицию, согласно которой субъектами независимой оценки являются фризические и юридические лица, получившие должную аккредитацию. Тем самым они подтверждают правомерность соответствующей формулировки, используемой муниципалитетами.

Так, Р.О. Долотов подчеркивает, что участвовать в независимой оценке могут только граждане и институты гражданского общества, получившие аккредитацию, и проводить ее они могут лишь за собственный счет [27].

С.В. Шаклеин выступает за привлечение в качестве независимых экспертов людей, на которых нормативный правовой акт отразится непосредственно, так как наличие коррупциогенных фракторов действительно повлияет на их деятельность [28]. При этом не отрицается необходимость получения аккредитации. Также автор подчеркивает, что главным мотивом деятельности эксперта должно являться «самоутверждение его как личности, ...влияющей на процессы государственного строительства».

Мысль о тождественности субъекта независимой экспертизы и физического или юридического лица, получившего аккредитацию, прослеживается у Е.Н. Бырдина, Ю.Г. Бабаевой [29].

И.Г. Яковлев предлагает делить независимую экспертизу на официальную и неофициальную [30]. Если первая проводится аккредитованными независимыми экспертами, то вторая - гражданами и институтами гражданского общества. Позиция важна вполне последовательным, вытекающим из нее вопросом: какую роль играют в проведении независимой антикоррупционной экспертной оценки граждане и институты гражданского общества, не получившие необходимую аккредитацию?

Вторая группа авторов уделила достаточное внимание вышеназванному вопросу и не столь однозначна во взгляде на субъект независимой оценки. А.И. Морозова и О.С. Короткова отмечают, что суть института независимой экспертизы состоит во взаимодействии государства с гражданским обществом, международными организациями и гражданами в вопросе противодействия коррупции [31].

С.В. Маркиянов и Е.А. Егорычева утверждают, что необходимо проявление интереса к проведению антикоррупционной экспертизы различных институтов гражданского общества как «к возможности быть причастным к обузданию коррупции в стране» [32]. Аккредитованные эксперты, по их мнению, должны осуществлять призыв к совместному производству экспертизы, выступая «модераторами рассматриваемого процесса, взаимодействуя с одной стороны с активными гражданами» и с территориальными управлениями Министерства юстиции РФ - с другой.

Заслуживает внимания концепция А.О. Мелешко [33]. Исследователь правильно отмечает, что при проведении независимой экспертизы происходит реализация конституционных прав граждан участвовать в управлении государственными делами и обращаться в государственные и муниципальные органы. Автор добавляет, что соответствующая аккредитация предоставляет физическим и юридическим лицам субъективное право на проведение антикоррупционного исследования. Соответственно, возможно проведение экспертизы не только в инициативном порядке или в рамках указания закона, а на договорной основе [34]. Такой взгляд позволяет представителям гражданского общества и гражданам, не имеющим аккредитации, обращаться за проведением оценки к независимым экспертам.

Наиболее четко о назревшей проблеме говорит О.В. Андрюхина [35]. В своей работе она замечает, что введенная законом формула «граждане и институты гражданского общества» последующими подзаконными актами была неправомерно сужена до «получивших аккредитацию физических и юридических лиц». Пожалуй, это и есть та самая точка, от которой стоит отталкиваться при исследовании субъекта независимой экспертизы и правомерность которой так или иначе обосновывается представителями «второй группы авторов».

Значительный вклад в формирование института антикоррупционной экспертной оценки внес закон 2009 г. Для его понимания первостепенное значение имеет правильное уяснение норм ст. 5.

Они не ставят знак равенства между формами гражданского общества и гражданами с одной стороны и аккредитованными экспертами - с другой. Напротив, в статье содержится их прямое противопоставление. Предоставляя институтам гражданского общества и гражданам право проводить за собственный счет экспертизу нормативных правовых актов и проектов актов, закон использует другой термин для лиц, непосредственно проводящих антикоррупционную оценку, «эксперты по проведению независимой антикоррупционной экспертизы актов и их проектов». При этом нет никакого указания на синонимичность этих двух понятий.

Нужно отметить и пункт 3 той же статьи Закона об антикоррупционной экспертизе. Там применена третья конструкция - «гражданин или организация, проводившие независимую экспертизу». Скорее всего, в данном случае речь идет уже о независимых экспертах. Тем не менее такое 
положение не противоречит п. 1 статьи, указывая на участие экспертов лишь в качестве «агентов» институтов гражданского общества и граждан. Они осуществляют непосредственную оценку и занимаются процессуальными вопросами, например получение мотивированных ответов, их анализ и доведение до сведения лиц, инициировавших проведение исследования [36, с. 36].

Важно также обратиться к Правилам проведения антикоррупционной экспертизы, утвержденным правительством. Пункт 4 Правил продолжает норму Закона об антикоррупционной экспертизе и прямо указывает, что аккредитованные Министерством юстиции физические и юридические лица участвуют в проведении оценки в качестве экспертов по проведению оценки. При этом они не обязаны быть инициаторами оценки или проводить ее за собственный счет.

Другие акты федерального уровня, в том числе приказ Министерства юстиции [37], не вносят корректировок во взаимосвязь независимых экспертов с институтами гражданского общества и граждан.

Таким образом, обоснованным будет принять в качестве субъекта независимой антикоррупционной экспертной оценки муниципальных нормативных правовых актов и проектов муниципальных нормативных правовых актов институты гражданского общества и граждан, инициирующих и обеспечивающих проведение оценки.

Перед ответом на последний вопрос нужно определить свойство (свойства), которым необходимо обладать для получения статуса субъекта антикоррупционной экспертной оценки нормативных правовых актов и проектов таких актов. Данной теме посвящено не много комплексных научных работ [38], однако благодаря им, а также практике правового регулирования можно сделать определенные выводы.

Первое свойство, которым обладает субъект оценки, - это наличие институциональной возможности инициирования экспертизы и материального обеспечения ее проведения. Так, например, институты гражданского общества и граждане имеют право привлечь независимого эксперта к проведению исследования и осуществить финансирование его деятельности.

Вторым свойством, присущим субъекту экспертизы, выступает обязательность рассмотрения его заключения органами, организациями и должностными лицами, издавшими акт, а также иные способы воздействия на издателя документа в целях исключения коррупциогенных положений. Поэтому требование об изменении акта и заключение прокурора обязательны к рассмотрению органом, принявшим акт.

В соответствии с приведенными выше критериями граждане-жители могут считаться субъектами антикоррупционной экспертизы.

Как следует из специального закона [39], задачей местного самоуправления является решение вопросов местного значения населением муниципалитета непосредственно или опосредованно. Муниципальные нормативные правовые акты и, как следствие, муниципальное правотворчество выступают одним из инструментов решения вопросов местного значения, принадлежащих населению. Антикоррупционная экспертиза является элементом процесса муниципального правотворчества. Соответственно, жители образования имеют право участвовать в осуществлении оценки, представляющей собой элемент процесса местного правотворчества.

Процесс инициирования, выбора лица, ответственного за оценку, решение вопроса его материального обеспечения могут производиться жителями в рамках уже существующего институционального механизма: публичного мероприятия в форме собрания [40]. Также гражданин может лично осуществить оценку.

Второй составляющей статуса местных жителей в качестве субъекта экспертизы выступают институциональные формы обеспечения рассмотрения органами местного самоуправления заключения, составленного по итогам исследования. Такие формы можно разделить на три группы в зависимости от силы воздействия на процесс изменения акта или его проект: общие, специальные, суперформы.

Единственной общей формой воздействия выступает опрос жителей муниципалитета [41]. Результаты проведенного опроса носят рекомендательный характер, поэтому шансы на действительное внесение изменений в акт или проект акта невелики.

Первой специальной формой выступает право на обращение в органы местного самоуправления, предусмотренное как конституционными положениями, так и специальными законами, в том числе о принципах местного самоуправления. Такие обращения могут подаваться индивидуально или коллективно. Представляется, что наиболее приемлемой формой для заключения, составленного по результатам оценки, будет выступать обращение в виде предложения, то есть рекомендации по совершенствованию муниципального нормативного правового акта [42]. Согласно Закону об обращениях, гражданин имеет право представлять дополнительные материалы и документы, одним из которых и будет выступать заключение. Однако, несмотря на обязательность рассмотрения обращения и обязанность органов направить гражданину письменный 
ответ, реальное воздействие на орган - издателя акта зависит от воли такого органа. Он может проигнорировать заключение и отправить лишь формальный ответ.

Второй специальной формой следует признать собрание граждан [43]. Оно может инициироваться населением и вправе принимать обращение к муниципальным органам. Однако, несмотря на обязательность рассмотрения обращения и направления письменного ответа, данный вид воздействия имеет тот же недостаток, что и предыдущий.

Третья форма - публичные слушания. Она, как было отмечено ранее, является одним из основных инструментов исключения коррупциогенности актов в европейских правовых системах. Существует определенный перечень документов, слушания в отношении которых обязательны [44]. В данном случае жители взаимодействуют с другими правотворческими субъектами непосредственно. Тем не менее однозначно результаты экспертизы в данном случае также не являются императивными для правотворческих органов.

Специальные фрормы воздействия обладают качественно бо́льшими возможностями для устранения коррупциогенных фракторов из муниципальных актов и проектов таких актов, чем общие. Но суперформы обеспечивают местному населению возможность использовать свои правотворческие способности, минуя органы местного самоуправления либо действуя совместно с ними. Суперформами следует признать институт правотворческой инициативы граждан, муниципальный референдум и сход граждан, осуществляющий полномочия представительного органа муниципального образования [45].

Таким образом, содержание статуса жителей муниципального образования в качестве субъекта антикоррупционной экспертизы составляют, с одной стороны, институциональные возможности инициирования экспертизы и материального обеспечения ее проведения, с другой стороны возможность обеспечения рассмотрения заключения, составленного по результатам проведенной оценки органами и должностными лицами местного самоуправления, издавшими акт, иные способы воздействия на издателей документа в целях исключения коррупциогенных положений. Примечательно, что статус обеспечивается уже существующими институтами и введение дополнительных не требуется. Поэтому уже сейчас активная деятельность местного населения может значительно повысить эффективность реализации антикоррупционной экспертной оценкой своей задачи по предупреждению коррупциогенной преступности в сфере местного самоуправления.

\section{Ссылки и примечания:}

1. О противодействии коррупции : федер. закон от 25 дек. 2008 г. № 273-Ф3 : ред. от 3 нояб. 2015 г. // Российская газета. 2008. 30 дек.

2. Например, по состоянию на 21 декабря 2015 г. в федеральном реестре нормативных правовых актов зарегистриро$\begin{array}{lllll}\text { вано } 8827 & \text { актов } & \text { государственных органов } & \text { Республики } & \text { Татарстан }\end{array}$ (http://minjust.ru/sites/default/files/dekabr_svedeniya_o_sostoyanii_federalnogo_registra_npa_006_1512.xls). B то же время по состоянию на 22 июня 2016 г. количество нормативных правовых актов муниципальных образований, расположенных на территории РТ, равняется 70130 (http://zakon.scli.ru/ru/legal_texts/act_municipal_education/).

3. См.: Выступление Ю.Я. Чайки на заседании Совета по развитию местного самоуправления 31 января 2013 г. [Электронный ресурc]. URL: http://www.kremlin.ru/news/17397 (дата обращения: 23.06.2016).

4. См.: О противодействии коррупции в Республике Татарстан : закон Республики Татарстан от 4 мая 2006 г. № $34-$ ЗРТ // Ведомости Государственного Совета Татарстана. 2006. № 5. Ст. 1464.

5. Алексеев П.В., Панин А.В. Философия. 3-е изд., перераб. и доп. М., 2005. 608 с.

6. Кабанов П.А. Антикоррупционная экспертиза нормативных правовых актов и проектов нормативных правовых актов: опыт правового регулирования субъектов РФ // Юридическая техника. 2014. № 8. С. 172-182.

7. Новая философская энциклопедия : в 4 т. / под ред. В.С. Степина. М., 2001.

8. Философрская энциклопедия : в 5 т. / под ред. Ф.В. Константинова. М., 1960-1970.

9. Ядов В.А. Стратегия социологического исследования. Описание, объяснение, понимание социальной реальности. 3-е изд., испр. М., 2007. С. 62-63.

10. Котова О.А., Шаова Т.Г. Предмет судебной экспертизы // Вестник криминалистики. 2004. Вып. 2 (10). С. 47-50.

11. Там же.

12. Будатаров С.М. Антикоррупционная экспертиза правовых актов и их проектов: понятие, порядок проведения : специализированный учебный курс. Саратов, 2013. С. 26.

13. Там же.

14. Мелешко А.О. Административно-правовое регулирование антикоррупционной экспертизы правовых актов : дис. ... канд. юрид. наук. Омск, 2015. С. 33-34.

15. Дмитриев Д.А. К вопросу о расширении пределов антикоррупционной экспертизы, проводимой органами прокуратуры Российской Федерации // Актуальные проблемы экономики и права. 2012. № 4 (24). С. 15-18.

16. Мелешко А.О. Административно-правовое регулирование ... С. 41.

17. Ананских И.А., Труфранов А.Ю. Об антикоррупционной экспертизе нормативных правовых актов и антикоррупционном мониторинге в сфере физической культуры и спорта // Мир политики и социологии. 2013. № 11. С. 123-130 ; Кудашкин А.В. Антикоррупционная экспертиза: теория и практика : научно-практическое пособие. М., 2012. С. 88 ; Юлегина Е.И. Антикоррупционная, правовая, криминологическая экспертиза нормативных правовых актов (сравнительный анализ) // Актуальные проблемы экономики и права. 2014. № 3 (31). С. 197-204.

18. Дмитриев Д.А. Указ. соч.

19. Антикоррупционная экспертиза нормативных правовых актов и их проектов : терминологический словарь / под ред. П.А. Кабанова. М., 2010. С. $41,58,65$. 
20. Мелешко А.О. Административно-правовое регулирование ...

21. Там же. С. 30-31.

22. Каверзин М.Ю. Государство и местное самоуправление: проблемы взаимодействия // Вестник РУДН. Серия: Политология. 2003. № 4. С. 13-19.

23. Яковлев В.В. Государство и местное самоуправление: отдельные аспекты их взаимоотношений // Сибирский юридический вестник. 2000. № 4. С. 16.

24. Hanson R.L. Governing Partners: State-Local Relations in the United States. Boulder, 1998.

25. О ведении федерального регистра муниципальных нормативных правовых актов : постановление Правительства Российской Федерации от 10 сент. 2008 г. № 657 // Российская газета. 2008. 19 сент.

26. Яковлев В.В. Вопросы ответственности органов и должностных лиц местного самоуправления перед государством // Сибирский юридический вестник. 2005. № 3.

27. Долотов Р.О. Эффективность института независимой антикоррупционной экспертизы нормативных правовых актов и проектов нормативных правовых актов // Актуальные проблемы экономики и права. 2015. № 4 (36). С. 42-49.

28. Шаклеин С.В. Проблемы развития независимой антикоррупционной экспертизы // Право и безопасность. 2012. № 3-4 (43). С. 84-87.

29. Бырдин Е.Н. Региональная практика правового регулирования независимой антикоррупционной экспертизы нормативных правовых актов // Академический вестник. 2014. № 2 (28). С. 65-69.

30. Яковлев И.Г. Независимая экспертиза на коррупциогенность и законодательная деятельность // Управление мегаполисом. 2011. № 3. С. 9-17.

31. Морозова А.И. Некоторые причины неэффективности работы института независимых экспертов и проблемы применения методики проведения антикоррупционной экспертизы // Вестник Тверского государственного университета. Серия: Право. 2014. № 4. С. 199-209.

32. Маркиянов С.В., Егорычева Е.А. Проблемы проведения независимой экспертизы: мнение и предложения независимых экспертов // Мониторинг правоприменения. 2012. № 1. С. 36-38.

33. Мелешко А.О. Административно-правовое регулирование ...

34. Там же. С. 36.

35. Андрюхина О.В. Правовые аспекты законодательного регулирования независимой антикоррупционной экспертизы: проблемы, стратегия, изменения // Юридическая техника. 2015. № 9. С. 96-99.

36. Мелешко А.О. Административно-правовая характеристика независимой антикоррупционной экспертизы и правового статуса независимых экспертов // Вестник Челябинского государственного университета. 2012. № 29 (283). С. 34-40.

37. Об аккредитации юридических и физических лиц в качестве независимых экспертов, уполномоченных на проведение экспертизы проектов нормативных правовых актов и иных документов на коррупциогенность: приказ Министерства юстиции Российской Федерации от 31 марта 2009 г. № 92 г. (Москва) // Российская газета. 2009. 29 апр.

38. Ермакова А.В. Антикоррупционная экспертиза как элемент законодательного процесса в субъектах РФ (на примере субъектов РФ, входящих в Южный федеральный округ) : дис. ... канд. юрид. наук. М., 2014. 185 с. ; Мелешко А.О. Административно-правовое регулирование ...

39. Об общих принципах организации местного самоуправления в Российской Федерации : федер. закон от 6 окт. 2003 г. № 131-Ф3 : ред. от 3 апр. 2017 г. // Собрание законодательства РФ. 2003. № 40. 6 окт. Ст. 3822.

40. О собраниях, митингах, демонстрациях, шествиях : федер. закон от 19 июня 2004 г. № 54-Ф3 : ред. от 3 июля 2016 г. // Российская газета. 2004. 23 июня.

41. Об общих принципах организации местного самоуправления в Российской Федерации

42. О порядке рассмотрения обращений граждан Российской Федерации : федер. закон от 2 мая 2006 г. № 59 -Ф3 : ред. от 3 нояб. 2015 г. // Российская газета. 2006. 5 мая. Ст. 4.

43. Об общих принципах организации местного самоуправления в Российской Федерации.

44. Там же.

45. Там же.

\section{References}

Alekseev, PV \& Panin, AV 2005, Philosophy, 3rd ed., Moscow, 608 p., (in Russian)

Ananskikh, IA \& Trufanov, AYu 2013, 'On anti-corruption examination of laws and regulations and anti-corruption monitoring in physical education and sports', Mir politiki i sotsiologii, no. 11, pp. 123-130, (in Russian).

Andryukhina, OV 2015, 'Legal aspects of legislative regulation of independent anticorruption examination: problems, strategy, changes', Yuridicheskaya tekhnika, no. 9, pp. 96-99, (in Russian).

Budatarov, SM 2013, Anticorruption examination of laws and regulations and their drafts: concept, procedure: a specialized training course, Saratov, p. 26, (in Russian).

Byrdin, EN 2014, 'Regional practice of legal regulation of independent anticorruption examination of laws and regulations', Akademicheskiy vestnik, no. 2 (28), pp. 65-69, (in Russian).

Dmitriev, DA 2012, 'Concerning the issue of expanding the limits of anticorruption examination conducted by the prosecutor's office of the Russian Federation', Aktual'nyye problemy ekonomiki i prava, no. 4 (24), pp. 15-18, (in Russian).

Dolotov, RO 2015, 'Efficiency of the institute of independent anticorruption examination of laws and regulations and their drafts', Aktual'nyye problemy ekonomiki i prava, no. 4 (36), pp. 42-49, (in Russian).

Ermakova, AV 2014, Anticorruption examination as an element of the legislative process in the constituent entities of the Russian Federation (case study of the constituent entities of the Russian Federation included in the Southern Federal District),

$\mathrm{PhD}$ in Law thesis, Moscow, 185 p., (in Russian).

Hanson, RL 1998, Governing Partners: State-Local Relations in the United States, Boulder.

Kabanov, PA 2014, 'Anticorruption examination of laws and regulations and their drafts: experience of legal regulation of the constituent entities of the Russian Federation', Yuridicheskaya tekhnika, no. 8, pp. 172-182, (in Russian).

Kabanov, PA (ed.) 2010, Anticorruption examination of laws and regulations and their drafts: a terminological dictionary, Moscow, pp. 41, 58, 65, (in Russian).

Kaverzin, MYu 2003, 'State and local self-government: problems of interaction', Vestnik RUDN. Seriya: Politologiya, no. 4 pp. 13-19, (in Russian).

Konstantinov, FV (ed.) 1960-1970, Philosophical encyclopedia, in 5 vols., Moscow, (in Russian)

Kotova, OA \& Shaova, TG 2004, 'Subject of forensic examination', Vestnik kriminalistiki, Issue 2 (10), pp. 47-50, (in Russian). 
Kudashkin, AV 2012, Anticorruption examination: theory and practice: a scientific and practical guide, Moscow, p. 88, (in Russian).

Markiyanov, SV \& Egorycheva, EA 2012, 'Problems of conducting an independent examination: opinion and suggestions of independent experts', Monitoring pravoprimeneniya, no. 1, pp. 36-38, (in Russian).

Meleshko, AO 2012, 'Administrative and legal characteristics of independent anticorruption examination and the legal status of independent experts', Vestnik Chelyabinskogo gosudarstvennogo universiteta, no. 29 (283), pp. 34-40, (in Russian).

Meleshko, AO 2015, Administrative and legal regulation of anticorruption examination of laws and regulations, $\mathrm{PhD}$ in Law thesis, Omsk, pp. 33-34, (in Russian).

Morozova, Al 2014, 'Some reasons for the ineffective activities of independent experts and the problems of applying the methods of carrying out anticorruption examination', Vestnik Tverskogo gosudarstvennogo universiteta. Seriya: Pravo, no. 4, pp. 199-209, (in Russian).

'On counteracting corruption in the Republic of Tatarstan: law of the Republic of Tatarstan No. 34-ZRT as of May 4, 2006' 2006, Vedomosti Gosudarstvennogo Soveta Tatarstana, no. 5, Article 1464, (in Russian).

Shaklein, SV 2012, 'Problems of development of independent anticorruption examination', Pravo i bezopasnost', no. 3-4 (43), pp. 84-87, (in Russian).

Speech of Yu.Ya. Chaika at the meeting of the Council for the Development of Local Self-Government on January 31, 2013 2016, viewed 23 June 2016, <http://www.kremlin.ru/news/17397>, (in Russian).

Stepin, VS (ed.) 2001, New philosophical encyclopedia, in 4 vols., Moscow, (in Russian).

Yadov, VA 2007, Strategy of sociological research. Description, explanation, understanding of social reality, 3rd ed., Moscow, pp. 62-63, (in Russian).

Yakovlev, IG 2011, 'Independent anticorruption examination and legislative activity', Upravleniye megapolisom, no. 3, pp. 917, (in Russian).

Yakovlev, VV 2000, 'State and local self-government: certain aspects of their mutual relations', Sibirskiy yuridicheskiy vestnik, no. 4, p. 16, (in Russian).

Yakovlev, VV 2005, 'Issues of responsibility of local self-government authorities and officials to the state', Sibirskiy yuridicheskiy vestnik, no. 3, (in Russian).

Yulegina, El 2014, 'Anticorruption, legal, criminological examination of laws and regulations (comparative analysis)', Aktual'nyye problemy ekonomiki i prava, no. 3 (31), pp. 197-204, (in Russian). 